\title{
PENERAPAN METODE PEMBELAJARAN IMPROVE UNTUK MENINGKATKAN AKTIVITAS DAN PRESTASI BELAJAR MATEMATIKA SISWA KELAS VIII-3 SMP LABORATORIUM UNDIKSHA SINGARAJA
}

\author{
N.D.T.U.Wulandari, D.Waluyo, I.M.Suarsana \\ Jurusan Pendidikan Matematika \\ Universitas Pendidikan Ganesha Singaraja, Indonesia \\ e-mail: niluhdevi23@yahoo.com,waluyo.dk@gmail.com, suarsana1983@gmail.com
}

\begin{abstract}
Abstrak
Penelitian ini bertujuan untuk mendeskripsikan : 1) peningkatan aktivitas belajar matematika siswa 2) peningkatan prestasi belajar matematika siswa dan 3) respon siswa terhadap penerapan metode pembelajaran IMPROVE Kelas VIII 3 SMP Laboratorium Undiksha. Jenis penelitian ini adalah penelitian tindakan kelas yang terdiri atas tiga siklus. Subjek penelitian ini adalah siswa Kelas VIII 3 SMP Laboratorium Undiksha Singaraja sebanyak 33 orang. Data aktivitas belajar siswa dikumpulkan dengan lembar observasi dan data prestasi belajar matematika dikumpulkan dengan tes uraian. Semua data yang dikumpulkan dianalisis secara deskriptif. Hasil penelitian menunjukkan bahwa terjadi peningkatan rata-rata skor aktivitas belajar matematika siswa dari siklus I ke siklus II sebesar 2,86 , yaitu dari 55,50 menjadi 58,36 , dan peningkatan dari siklus II ke siklus III sebesar 9,09, yaitu 58,36 menjadi 67,45 . Peningkatan ini terjadi akibat adanya diskusi secara terus menerus yang mengakibatkan meningkatnya aktivitas belajar siswa. Selain aktivitas belajar, rata-rata skor prestasi belajar matematika siswa juga meningkat, dari siklus I ke siklus II meningkat sebesar 18,64, yaitu dari 48,03 menjadi 66,67 dan dari siklus II ke siklus III terjadi peningkatan sebesar 10,15 yaitu dari 66,67 menjadi 76,82 . Terjadinya peningkatan prestasi belajar diakibatkan oleh pemberian metacognitive questioning pada diskusi kelompok yang dapat membantu siswa untuk menemukan suatu konsep. Adapun respon positif yang diperoleh dari penerapan metode pembelajaran IMPROVE yang menunjukkan bahwa siswa dapat mengikuti proses pembelajaran dengan baik dengan skor rata-rata adalah 69,03 .
\end{abstract}

Kata kunci: metode pembelajaran improve, prestasi belajar matematika, aktivitas belajar matematika

\section{Abstract}

This research was aimed to describe 1) the improvement of students' learning activity of mathematics 2) the improvement of students' learning achievement of mathematics, and 3) Students response toward IMPROVE learning method implementation in VIII 3 SMP Laboratorium Undiksha. This research was a classroom action research which was conducted in three cycles. The subject of this research was the students in class VIII-3 SMP Laboratorium Undiksha Singaraja consisted of 33 students. Data of the students' learning activity of mathematics was obtained by observation and data of the students' learning achievement of mathematics was obtained by essay test. All of the data that had been collected were then analyzed descriptively. The results of this research show that there is improvement of learning activity of mathematics, from the first cycle to the second cycle is 2,86, it is from 55,50 to 58,36; the improvement from the second cycle to the third cycle is 9,09, it was from 58,36 to 67,45 . This increase occurs due to continuous discussion which resulted in increased student learning activities. Besides the learning activity of mathematic, the students' average score of learning achievement mathematics also improves, from the first cycle to the second cycle the average score improves 18,64, it is from 48,03 to 66,67; from the second cycle to the third cycle the average score improves 10,15, it is from 66,67 to 76,82. The increase in learning achievement is caused by the provision of metacognitive questioning on group discussions that can help students to find a concept. Students also give positive response to the implementation of IMPROVE learning method with an average score of 69.03. The positive response obtained from the application of IMPROVE learning method that shows that students can follow the learning process well with the average score is 69.03.

Key words: Improve method, learning achievement of mathematics, learning activity of mathematics. 


\section{Pendahuluan}

Matematika merupakan salah satu mata pelajaran yang dipelajari oleh semua siswa, dari Sekolah Dasar, Sekolah Menengah Pertama hingga Perguruan Tinggi yang memiliki peran yang sangat penting bagi perkembangan ilmu-ilmu yang lain. Selain itu, Matematika juga penting karena selain sebagai ilmu juga berfungsi sebagai alat dan pola pikir (Suherman, 2001). Tujuan diberikannya pembelajaran matematika di sekolah mencakup 4 tujuan utama, yaitu (1) Melatih cara berfikir dan bernalar dalam menarik kesimpulan. (2) Mengembangkan aktivitas kreatif yang melibatkan imajinasi, intuisi, dan penemuan dengan mengembangkan pemikiran divergen, orisinil, rasa ingin tahu, membuat prediksi dan dugaan, serta mencoba-coba. (3) Mengembangkan kemampuan pemecahan masalah. (4) Mengembangkan kemampuan menyampaikan informasi dan mengkomunikasikan gagasan. Penerapan pembelajaran matematika merupakan cara untuk mengetahui fakta, konsep, prinsip, dan proses terkait fenomena alam. Mencari dan menemukan solusi terhadap masalah yang ada dengan cara diskusi dengan komunikasi dua arah antara guru dan siswa akan menyebabkan keaktifan siswa meningkat. Oleh karena itu, pembelajaran di kelas dalam rangka pembentukan konsep kepada siswa merupakan cara belajar yang dapat menghasilkan aktivitas yang baik.

Oemar Hamalik (2009: 179) menyatakan bahwa aktivitas belajar merupakan kegiatan yang dilakukan oleh siswa dalam kegiatan pembelajaran. Saat pembelajaran berlangsung, siswa mampu memberikan umpan balik terhadap guru. Proses pembelajaran yang dilakukan di dalam kelas merupakan aktivitas mentransformasikan pengetahuan, sikap, dan keterampilan. Aktivitas belajar dapat terwujud apabila siswa terlibat belajar secara aktif. Martinis Yamin (2007: 82) menyatakan bahwa belajar aktif merupakan usaha manusia untuk membangun pengetahuan dalam dirinya. Pembelajaran akan menghasilkan suatu perubahan dan peningkatan kemampuan, pengetahuan, dan ketrampilan pada diri siswa. Sehingga siswa mampu menggali kemampuannya dengan rasa ingin tahunya sehingga interaksi yang terjadi akan menjadi pengalaman dan keinginan untuk mengetahui sesuatu yang baru. Berdasarkan hal tersebut maka dapat dikatakan bahwa aktivitas memiliki peranan penting dalam pelaksanaan pembelajaran matematika.

Tingkat aktivitas belajar yang dilakukan siswa tentunya berdampak pada prestasi belajar siswa itu sendiri. Alci (2015) menyatakan bahwa siswa dengan aktivitas belajar yang tinggi akan menghasilkan pencapaian atau prestasi belajar yang tinggi pula. Sebaliknya siswa dengan aktivitas belajar yang dilakukan oleh siswa rendah, maka pencapaian atau prestasi belajar yang diraih akan rendah.

Salah satu masalah utama dalam pembelajaran matematika adalah bagaimana menghubungkan fakta yang pernah dilihat dan dialami siswa dalam kehidupan sehari-hari dengan konsep matematika, sehingga menjadikan pengetahuan yang bermakna bagi siswa di semua jenjang pendidikan. Pemerintah mengupayakan pembaharuan pendidikan secara terencana, terarah dan berkesinambungan. Hal ini ditunjukkan dengan ditetapkannya Undang-Undang No. 20 Tahun 2003 tentang sistem pendidikan nasional. UU No. 20 Tahun 2003 memberikan mandate pada setiap sekolah/ kelompok sekolah dan komite sekolah wajib menyusun kurikulum yang digunakan sebagai acuan penyelenggaraan proses pendidikan di satuan pendidikan tersebut, dengan tetap mengacu pada Standar Nasional Pendidikan. Oleh karena itu muncullah Kurikulum Tingkat Satuan Pendidikan (KTSP).

Penerapan kurikulum KTSP merupakan salah satu upaya untuk meningkatkan aktivitas dan prestasi belajar siswa. Dalam pembelajaran di kelas, pembelajaran dilakukan dengan student center, sehingga diharapkan dengan adanya penerapan kurikulum KTSP, siswa dapat belajar dengan baik dan dapat meningkatkan aktivitas dan prestasi belajar siswa. Selain itu, penerapan kurikulum dilakukan dengan harapan untuk meningkatkan mutu pendidikan. Layaknya suatu inovasi kurikulum diharapkan dapat membawa perbaikan dalam proses pendidikan yang pada akhirnya dapat meningkatkan mutu pendidikan, untuk masa depan yang lebih baik bagi anak-anak bangsa. 
Harapan tersebut belum terealisasi dengan hasil penelitian yang dilakukan oleh Aritami (2016) yang menunjukkan bahwa sebagian siswa kurang menyukai pembelajaran matematika karena menganggap pelajaran matematika sebagai pelajaran yang sulit. Hasil senada diperoleh dari hasil observasi terhadap proses pembelajaran matematika di Kelas VIII 3 SMP Laboratorium Undiksha semester genap tahun pelajaran 2017/2018. Hasil observasi ini menunjukkan sebagian siswa memiliki aktivitas belajar yang cukup rendah karena tindakan yang ditunjukkan oleh siswa belum sepenuhnya memenuhi dimensi aktivitas yang baik. Hasil observasi menunjukkan bahwa beberapa siswa tidak mengikuti pembelajaran dengan baik (indikator antusiasme siswa dalam mengikuti kegiatan pembelajaran), beberapa siswa tidak bertanya kepada guru apabila terdapat materi yang belum dikuasai (indikator interaksi dengan guru), terdapat siswa yang tidak bekerja sama dalam diskusi kelompok (indikator kerjasama kelompok). Hasil ini menunjukkan rendahnya aktivitas belajar siswa. Rendahnya aktivitas belajar siswa diprediksi disebabkan oleh strategi, model, metode atau pendekatan pembelajaran yang diterapkan oleh guru dikelas. Pembelajaran dikelas cenderung bersifat teachercentered, menyebabkan siswa menjadi pendengar yang baik, menjadi bosan, mengantuk, pasif, dan berfungsi sebagai notulis dari ucapan guru di depan kelas saja (Mutoharoh, 2011).

Rendahnya prestasi belajar siswa Kelas VIII 3 SMP Laboratorium Undiksha yang sedang melaksanakan pembelajaran di semester genap Kelas VIII tercermin dari nilai ulangan harian III tahun ajaran 2016/2017 mata pelajaran matematika yang disajikan pada Tabel 1.

Tabel 1.Nilai Ulangan Harian III tahun ajaran 2016/2017

\begin{tabular}{lccccc}
\hline \multicolumn{1}{c}{ Aspek } & \multicolumn{5}{c}{ Kelas VIII } \\
\cline { 2 - 6 } Nilai Tertinggi & 1 & 2 & 3 & 4 & 5 \\
Nilai Terendah & 95 & 87,0 & 70,5 & 86,5 & 80,7 \\
Rata-rata & 78 & 72,5 & 60 & 73,5 & 75,8 \\
Frekuensi $\geq$ KKM 75 & 81,7 & 80,5 & 64 & 81,2 & 79,9 \\
Frekuensi < KKM 75 & 25 & 26 & 20 & 29 & 23 \\
Jumlah siswa yang belum & 9 & 7 & 13 & 4 & 8 \\
mencapai KKM & 9 & 7 & 14 & 4 & 8 \\
Ketuntasan Klasikal (\%) & $85 \%$ & $77,5 \%$ & $52 \%$ & $72,5 \%$ & $55 \%$ \\
\hline
\end{tabular}

(Sumber: Nilai Guru Pengajar Kelas VIII SMP Lab Undiksha)

Berdasarkan Tabel 1 terungkap bahwa dari 5 kelas tersebut Kelas VIII 3 memperoleh nilai rata-rata paling rendah yaitu 64 .

Proses pembelajaran matematika seharusnya menekankan pada pemberian pengalaman langsung pada siswa untuk menumbuhkan kemampuan berpikir, bekerja dan bersikap ilmiah, serta mengomunikasikannya sebagai aspek penting kecakapan hidup (Susilo, 2012). Berdasarkan hasil observasi lanjutan pada proses pembelajaran di Kelas VIII 3 SMP Laboratorium Undiksha semester genap tahun pelajaran 2017/2018 teridentifikasi sebab munculnya permasalahan sebagai berikut, 1) melalui angket mengenai aktivitas belajar, siswa masih menganggap bahwa matematika pelajaran yang sulit, ilmu abstrak/ tidak berhubungan dengan realita dan cenderung membosankan, dalam proses pembelajaran matematika siswa cenderung pasif sehingga mengakibatkan siswa cenderung pasif sehingga mengakibatkan sebagian besar siswa malu dan enggan bertanya pada guru maupun teman yang lain mengenai materi yang kurang dipahami ataupun permasalahan yang terjadi di kelas 2) Siswa kesulitan untuk belajar kelompok, hal ini dikarenakan pembagian kelompok yang tidak heterogen dari segi akademis sehingga ada kelompok yang kesulitan untuk menyelesaikan masalah yang diberikan 3) Siswa yang telah mampu 
memahami materi pelajaran tidak memiliki inisiatif untuk membantu temannya yang belum paham sehingga jika diberikan suatu tes hanya sedikit siswa yang dapat melampaui KKM atau tuntas dalam pembelajaran, padahal apabila siswa aktif dan bisa saling bekerjasama maka pembelajaran dalam pembelajaran dapat diminimalisir, 4) dalam pembelajaran, siswa hanya sibuk mencatat apa yang disampaikan oleh guru. Siswa hanya mengingat apa yang dijelaskan oleh guru tanpa adanya usaha untuk mengembangkan pengetahuannya terhadap konsep baik itu antara guru maupun diskusi bersama teman yang lain, selain itu apabila diberikan soal atau permasalahan yang sedikit berbeda dengan soal yang diberikan sebelumnya, siswa akan kebingungan dalam menyelesaikannya.

Kesenjangan antara harapan dan kenyataan yang terjadi menyebabkan timbulnya permasalahan dalam pendidikan yang mengakibatkan rendahnya prestasi belajar dan aktivitas belajar siswa. Berdasarkan identifikasi permasalahan tersebut maka perlu adanya perbaikan proses pembelajaran. Guru dituntut untuk memiliki kreativitas yang tinggi dalam memilih metode pembelajaran untuk dapat menarik minat siswa. Oleh karena itu, agar upaya peningkatan aktivitas dan prestasi belajar dapat berhasil maka metode pembelajaran harus dipilih yang sesuai dengan situasi dan kondisi siswa. Pemilihan metode pembelajaran yang tepat juga akan memperjelas konsep-konsep yang diberikan agar siswa antusias berpikir dan berperan aktif dalam pembelajaran. Solusi yang tepat untuk mengatasi permasalahan tersebut adalah penggunaan metode pembelajaran yang inovatif. Salah satu metode pembelajaran inovatif yang dapat diterapkan oleh guru dalam pembelajaran matematika adalah metode pembelajaran IMPROVE. Metode pembelajaran IMPROVE merupakan salah satu metode yang memiliki tingkat kebermaknaan tinggi. Dalam metode ini, siswa dikenalkan pada suatu konsep baru, diberikan pertanyaan-pertanyaan metakognitif oeh guru dan kemudian berlatih menyelesaikan permasalahan terkait materi. Salah satu komponen metode ini adalah kerjasama. Kerjasama itu dapat membantu siswa menemukan kekuatan serta kelemahan diri. Mendengarkan pendapat orang dengan pikiran terbuka, dan menciptakan persetujuan bersama dalam mengambil keputusan. Peran guru dalam pembelajaran adalah memfasilitasi berlangsungnya diskusi. Metode Improve juga telah diterapkan oleh Nur Rafida Herawati pada penelitian di Kelas X MIA 1 SMA Negeri 1 Sukoharjo yang dapat meningkatkan kerjasama siswa dalam berdiskusi yang membuat siswa berperan aktif saat bekerjasama dalam kelompok serta mampu menyelesaikan permasalahan yang diberikan.

Implementasi metode Improve diharapkan mampu menambah nuansa baru bagi siswa serta dapat mengoptimalkan kemampuan siswa secara maksimal. Selain itu juga agar pembelajarannya dapat memberikan pengaruh positif terhadap prestasi dan aktivitas dalam pembelajaran meningkat.

Berdasarkan uraian di atas, maka dilakukan langkah perbaikan proses pembelajaran matematika dengan berkolaborasi bersama guru melakukan penelitian tindakan kelas dengan judul penelitian "Penerapan Metode Pembelajaran IMPROVE untuk Meningkatkan Aktivitas dan Prestasi Belajar Matematika Siswa Kelas VIII 3 SMP Laboratorium Undiksha Singaraja"

\section{Metode}

Penelitian yang dilaksanakan ini adalah penelitian tindakan kelas. Penelitian ini dilaksanakan dalam tiga siklus dimana setiap siklus terdiri dari empat tahapan yaitu perencanaan tindakan, pelaksanaan tindakan, observasi/evaluasi, dan refleksi. Penelitian ini bersifat kolaboratif yaitu peneliti bekerjasama dengan guru matematika yang mengajar di kelas tersebut, sehingga penelitian ini diharapkan dapat memberikan hasil yang optimal.

Subjek dalam penelitian ini adalah siswa kelas VIII-3SMP Laboratorium Undiksha Singaraja sebanyak 33 orang. Sedangkan, objek dalam penelitian ini adalah (1) aktivitas belajar matematika siswakelas VIII-3 SMP Laboratorium UndikshaSingaraja, (2) prestasi belajar matematika siswa kelas VIII-3 SMP Laboratorium Undiksha (3) respon siswa terhadap pembelajaran matematika setelah metode pembelajaran IMPROVE. 
Instrumen dalam penelitian ini berupa lembar obeservasi, tes dan angket. Lembar observasi digunakan untuk mengobservasi aktivitas belajar siswa setiap pertemuan. Tes yang digunakan untuk mengumpulkan data prestasi belajar matematika siswa berbentuk soal uraian. Sedangkan angket digunakan untuk mengumpulkan data mengenai respon siswa terhadap penerapan metode pembelajaran IMPROVE.

Data yang terkumpul selanjutnya dianalisis secara deskriptif, yaitu dengan menghitung skor aktivitas belajar siswa selama 9 pertemuan, danskor prestasi belajarmatematika siswa yang ditinjau dari Kriteria Ketuntasan Minimal (KKM) Mata Pelajaran Matematika dan ketuntasan belajar siswa secara klasikal serta rata-rata skor respon siswa untuk data respon siswa. Kriteria yang digunakan dalam penggolongan aktivitas belajar matematika siswa, prestasi belajar matematika siswa dan respon terhadap metode pembelajaran IMPROVE disajikan pada Tabel 2,3, dan 4.

Tabel 2. Kriteria Skor Aktivitas Belajar Siswa

\begin{tabular}{ll}
\hline Rentang Skor & Kategori \\
\hline $\bar{A} \geq 80,00$ & Sangat Aktif \\
\hline $60,00 \leq \bar{A}<80,00$ & Aktif \\
\hline $40,00 \leq \bar{A}<60,00$ & Cukup \\
\hline $20,00 \leq \bar{A}<40,00$ & Kurang Aktif \\
\hline $\bar{A}<20,00$ & Tidak Aktif \\
\hline
\end{tabular}

(Dimodifikaasi dari Candiasa, 2010)

Tabel 3. Kriteria Ketuntasan Prestasi Belajar Matematika Siswa

\begin{tabular}{cc}
\hline Rentangan Nilai & Kategori \\
\hline $75 \leq \bar{X} \leq 100$ & Tuntas \\
$0 \leq \bar{X}<75$ & Belum Tuntas \\
\hline
\end{tabular}

\begin{tabular}{cc} 
Tabel 4. Kriteria Penggolongan Respon Siswa \\
\hline Rentang Skor & Kategori \\
\hline $\bar{R} \geq 83,94$ & Sangat Positif \\
\hline $67,98 \leq \bar{R}<83,94$ & Positif \\
$52,02 \leq \bar{R}<67,98$ & Cukup \\
$36,06 \leq \bar{R}<52,02$ & Negatif \\
$\bar{R}<36,06$ & Sangat Negatif \\
\hline
\end{tabular}

(Dimodifikaasi dari Candiasa, 2010)

\section{Hasil dan Pembahasan}

A. Aktivitas Belajar Matematika Siswa

Berikut data aktivitas belajar matematika siswa terhadap implementasi metode pembelajaran IMPROVE yang disajikan pada Gambar 1 berikut. 


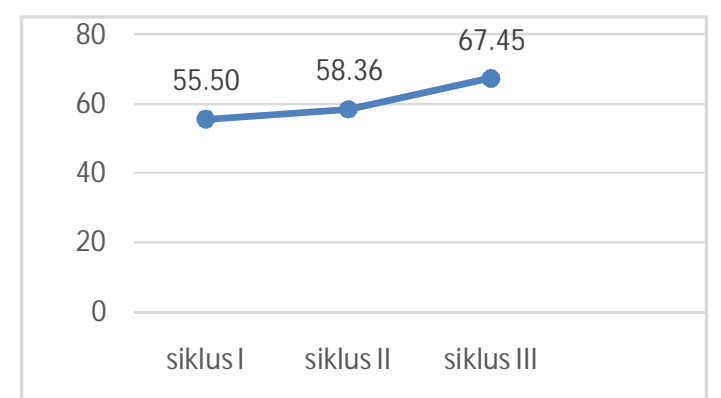

Gambar 3. Peningkatan Rata-rata Skor Aktivitas Belajar Siswa.

Dalam gambar 1 secara umum telah terjadi peningkatan aktivitas belajar siswa dari siklus I sampai siklus III. Pada siklus I, rata-rata skor aktivitas belajar siswa adalah 55,50. Selanjutnya pada siklus II, rata-rata skor aktivitas belajar siswa adalah 58,36 . Berdasarkan rata-rata skor tersebut, maka aktivitas belajar siswa dari siklus I ke siklus II mengalami peningkatan sebesar 2,86. Peningkatan aktivitas belajar juga terjadi dari siklus II ke siklus III sebesar 9,09, yaitu dari 58,36 pada siklus II menjadi 67,45 pada siklus III.

B. Prestasi Belajar Matematika Siswa

Berdasarkan hasil penelitian yang telah dilaksanakan, prestasi belajar matematika siswa Kelas VIII-3 SMP Laboratorium Undiksha Singaraja dari siklus I sampai siklus III dapat dinyatakan dalam gambar 2 .

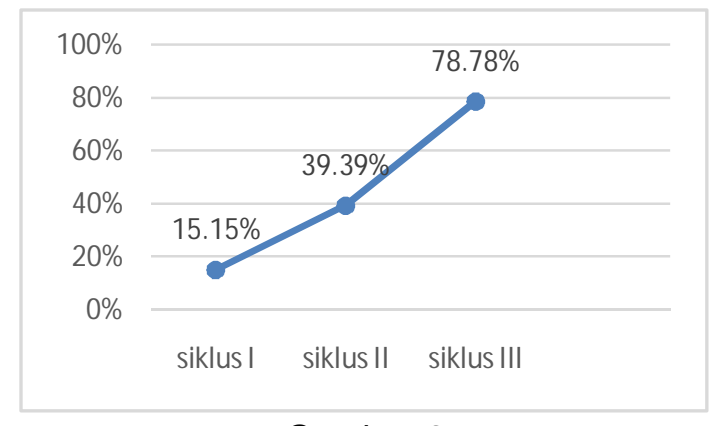

Gambar 2.

Data Peningkatan Ketuntasan BelajarMatematika Siswa pada Siklus I,II, danIII.

Dari gambar 2 secara umum dapat dilihat bahwa ketuntasan belajar belajar matematika siswa meningkat setiap siklusnya. Pada siklus I, ketuntasan belajar siswa adalah $15,15 \%$. Pada siklus II,ketuntasan belajar siswa adalah 39,39\%. Berdasarkan ketuntasan belajar yang terlihat bahwa dari siklus I menuju siklus II terjadi peningkatan sebesar $24,24 \%$. Selanjutnya, ketuntasan belajar pada siklus III juga mengalami peningkatan sebesar $39,39 \%$, yaitu dari $39,39 \%$ pada siklus II menjadi $78,78 \%$ pada siklus III.

\section{Respon Siswa}

Pada akhir siklus III, siswa mengisi angket untuk mengetahui respon siswa terhadap penerapan metode pembelajaran IMPROVE yang telah dilaksanakan. Angket respon ini terdiri atas 20 pernyataan. 


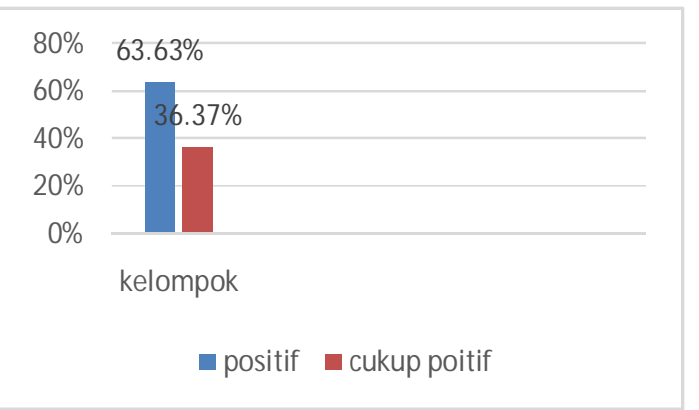

Gambar 3. Grafik Respon Siswa terhadap Metode Pembelajaran IMPROVE

Berdasarkan analisis data yang dilaksanakan, diperoleh bahwa rata-rataskor respon siswa sebesar 69,03. Hal inimenunjukkan siswa memberikan responpositif terhadap penerapan metodepembelajaran IMPROVE.

\section{Pembahasan}

Berdasarkan hasil penelitian yang telah dilaksanakan dalam tiga siklus terlihat bahwa prestasi belajar matematika dan aktivitas belajar siswa Kelas VIII 3 SMP Laboratorium Singaraja mengalami peningkatan dari siklus I sampai siklus III. Hal ini ditinjau dari rata-rata skor prestasi belajar matematika siswa dan aktivitas belajar siswa yang telah memenuhi indikator keberhasilan.

Dalam proses observasi sebelum dilakukannya tindakan kelas, terlihat beberapa siswa yang kurang aktif di kelas, diantaranya siswa dengan kode A09, A11, A17, A18, A27. Setelah diberikan suatu tindakan kelas di siklus I, keempat siswa tersebut masih belum terlihat aktif, namun di siklus II dan III perubahan yang terjadi cukup terlihat dari proses pembelajaran yang dilakukan di kelas dengan cara menunjuk mereka secara acak agar aktif di depan kelas. Awalnya memang harus dipaksa terlebih dahulu, maka di kemudian hari siswa tersebut akan terbiasa untuk aktif dan dapat mengutarakan pendapatnya di depan kelas.

Berawal dari skilus I, rata-rata skor prestasi belajar siswa adalah 48,03, inimenunjukkan bahwa rata-rata skor prestasi belajar siswa belum memenuhi indikator keberhasilan, karena belum mecapai nilai KKM. Skor aktivitas belajar siswa pada siklus I adalah 55,50, hal ini juga belum memenuhi indikator keberhasilan dan termasuk dalam kategori "Cukup Aktif". Hal ini disebabkan karena pada siklus I terjadi beberpa permasalahan dalam pelaksanaan tindakan seperti yang telah dipaparkan pada refleksi siklus I sebelumnya. Dari permasalahan yang terjadi sudah dilakukan beberapa upaya untuk mengatasinya.

Kemudian pada siklus II, terjadi peningkatan skor prestasi belajar dan aktivitas belajar siswa dari siklus I. Pada siklus II, skor pemahaman konsep matematika siswa adalah 66,67 dan berada pada kategori Cukup. Sedangkan rata-rata skor aktivitas belajar siswa adalah 58,36 dan berada pada kategori cukup aktif. Berdasarkan skor tersebut terlihat sudah terjadi peningkatan dari siklus I, namun masih belum mencapai indikator keberhasilan yang diharapkan. Peningkatan pada siklus II terjadi karena telah dilakukan perbaikan-perbaikan sebagai upaya untuk menyempurnakan proses pembelajaran dengan menggunakan metode pembelajaran IMPROVE. Pada siklus II guru dan siswa mulai terbiasa dan dapat menyesuaikan diri dalam mengikuti pembelajaran dengan metode pembelajaran IMPROVE. Guru sudah dapat memberikan Metacognitive question sesuai dengan tingkat pemahaman siswa sehingga siswa dapat menanggapi pertanyaan guru dengan optimal. Selain itu juga setelah diberikan motivasi dan apresiasi siswa menjadi lebih aktif dalam menanaggapi pertanyaan guru ataupun bertanya kepada guru terkait dengan materi yang tidak di mengerti. Aktivitas siswa dalam kelompok pun sudah berjalan cukup optimal, ini terlihat saat siswa melaksanakan diskusi kelompok anggota kelompok sudah jarang asik mengobrol. Dengan 
demikian, dapat dikatakan bahwa pembelajaran pada siklus II dengan model pembelajaran IMPROVE sudah berjalan lebih kondusif dibandingkan dengan siklus I.

Meskipun pada siklus II, siswa sudah mengalami peningkatan prestasi belajar matematika dan aktivitas belajar siswa serta memenuhi indikator keberhasilan yaitu 66,67 untuk prestasibelajar dan 58,36 untuk aktivitas belajar, namun hasil dari prestasi belajar matematika masih belum memenuhi KKM yang ditentukan, dari 33 siswa hanya 13 orang siswa yang memenuhi nilai diatas KKM. Selain itu masih terdapat beberapa masalah pada siklus II seperti yang telah dipaparkan sebelumnya. Oleh sebab itu, perlu ditingkatkan lagi dengan melaksanakan tindakan pada siklus III.

Pada siklus III telah dilakukan upaya perbaikan pelaksanaan proses pembelajaran sesuai dengan refleksi dari siklus II, ternyata dengan perbaikan proses pelaksanaan pembelajaran tersebut terjadi peningkatan pada siklus III, baik itu rata-rata skor prestasi belajar matematika siswa maupun aktivitas belajar siswa. Pada siklus III, rata-rata skor prestasi belajar matematika adalah 76,82 dengan presentase ketuntasan belajar sebesar $78,78 \%$ hal ini menunjukkan bahwa sudah berada pada kategori tuntas dan telah memenuhi skor $\geq$ KKM, sedangkan untuk rata-rata skor aktivitas belajar siswa adalah 67,45 dan sudah berada pada kategori aktif. Dengan demikian sudah tercapai dua indikator keberhasilan yang ditetapkan. Hal ini disebabkan karena, pelaksanaan pembelajaran sudah berjalan optimal sesuai dengan rencana pelaksanaan pembelajaran yang direncanakan. Dengan teguran-teguran, motivasi dan apresiasi yang diberikan oleh guru, siswa pun mulai aktif berdiskusi dan bekerjasama dalam kelompoknya mereka mulai merasa memiliki tanggung jawab yang sama dalam mengerjakan LKS. Selain karena merasa memiliki tanggung jawab, siswa mulai aktif karena setelah mengerjakan LKS guru akan melakukan tanya jawab dengan menunjuk siswa secara acak. Sehingga mau tidak mau siswa yang ditunjuk harus mampu menjawab pertanyaan guru.

Berdasarkan hasil yang diperoleh, secara umum metode pembelajaran IMPROVE sudah mampu meningkatkan prestasi belajar dan aktivitas belajarmatematika siswa kelas VIII 3 SMP Laboratorium Undiksha Singaraja. Hal ini disebabkan oleh langkah-langkah pembelajaran pada metode pembelajaran IMPROVE, pada langkah pertama yaitu introducing the new concepts, guru berperan sebagai fasilitator untuk membimbing siswa menemukan konsep secara mandiri. Hal ini dicirikan dengan guru tidak memberikan begitu saja hasil akhir dari suatu konsep. Guru membimbing siswa menemukan suatu konsep dengan memberikan pertanyaan-pertanyaan yang mengarah pada penemuan suatu konsep. Langkah selanjutnya yaitu metacognitive questioning, guru sebagai fasilitator memberikan pertanyaan-pertanyaan bersifat metacognitive yang terdapat dalam LKS. Pertanyaan metacognitive merupakan pertanyaan yang mengarahkan siswa untuk berfikir tinngi terhadap suatu permasalahan yang sudah terdapat penyelesaiannya. Namun, di tahap pemberiam pertanyaan metacognitive pada LKS, siswa masih mengalami kebingungan di awal siklus, namun setelah diberikan penjelasan oleh guru, siswa mulai paham mengenai pertanyaan metacogniive. Hal ini serupa dengan penelitian yang dilakukan oleh Indah Oktarini (2015) yang menyatakan bahwa pertanyaan metacognitive terkadang membingungkan siswa, namun setelah siswa memahami apa itu pertanyaan metacognitive, maka siswa dapat dengan mudah menyelesaikanya. Selanjutnya pada langkah practicing, guru memberikan latihan kepada siswa secara kelompok yang terdiri dari 4-6 orang dalam bentuk soal-soal. Setelah memberikan latihan soal, saatnya guru melakukan pengulasan atau pembahasan terhadap kesulitan-kesulitan yang dialami siswa sewaktu memahami materi atau menjawab soal-soal. guru memberikan solusi guna menjawab kesulitan-kesulitan yang dialami siswa, dan guru akan mengetahui tingkat penguasaan materi siswa secara individu atau keseluruhan. Hal ini dapat dilakukan dengan memberikan tes kepada siswa sesuai dengan materi yang telah dipelajari. Selanjutnya, guru mengidentifikasi siswa yang telah memahami atau menguasai materi siswa yang belum menguasai materidengan melihat hasil tes yang telah diberikan pada tahap sebelumnya. Guru memberikan respon terhadap hasil verifiksi yaitu dengan memberikan soal pengayaan kepada siswa. 
Dalam proses pembelajaran, guru juga memberikan penghargaan dengan memberikan tambahan nilai ataupun gantungan kunci kepada siswa atau kelompok yang aktif dalam proses pembelajaran baik dalam mengemukakan pendapatnya ataupun menanggapi dan menyempurnakan jawaban dari temannya. Dengan memberikan penghargaan ini, siswa lebih termotivasi dan antusias dalam mengikuti pembelajaran sehingga ini juga diikuti dengan meningkatnya aktivitas belajar siswa. Temuan ini sejalan dengan penelitian Dewi Yuningsih (2016) yang menyatakan bahwa pembelajaran dengan berani aktif di depan kelas mampu meningkatkan prestasi belajar matematika siswa.

Selain mampu menigkatkan aktivitas dan prestasi belajar matematika siswa, implementasi metode pembelajaran IMPROVE juga mendapatkan respon positif dari siswa yaitu dengan rata-rata 69,03. Hasil respon ini menunjukkan bahwa siswa senang belajar matematika dengan metode tersebut. Respon positif siswa timbul karena siswa sudah mulai terbiasa belajar dengan metode yang diberikan dimana lebih menekankan siswa untuk mengkonstruksi sendiri ilmu yang dimiliki serta bisa sharing bersama temannya tanpa malu untuk mengajukan pertanyaan, memberikan gagasan ataupun menerima kritikan yang dapat meningkatkan pemahaman terhadap suatu materi. Hal ini serupa dengan penelitian yang dilakukan oleh Dina Nurhayati (2014) yang menyatakan bahwa "tanpa sharing siswa akan tersesat", kata-kata tersebut yang dapat menunjukkan bahwa dalam pembelajaran, siswa perlu sharing dengan teman maupun guru. Selain adanya hasil yang positif, berdasarkan analisis angket respon yang dibagikan kepada siswa diakhir siklus III, terdapat beberapa siswa yang masih kurang menyukai metode ini terutama pada proses pemberian pertanyaan metacognitive yang terdapat pada LKS. Namun hal ini perlu adanyaperbaikan-perbaikan kembali untuk penelitian selanjutnya.

Berdasarkan hasil yang diperoleh, secara umum penelitian ini telah mampu menjawab rumusan masalah mengenai peningkatan prestasi belajar dan aktivitas belajar matematika siswa. Penerapan metode pembelajaran IMPROVE dapat meningkatkan prestasi belajar dan aktivitas belajar matematika siswa Kelas VIII 3 SMP Laboratorium Undiksha Singaraja. Dengan demikian, dapat dikatakan bahwa penelitian tindakan kelas yang dilaksanakan berhasil.

\section{Simpulan dan Saran} berikut.

Berdasarkan hasil analisis data, temuan dan pembahasan, dapat disimpulkan hal-hal

Aktivitas belajar matematika siswa Kelas VIII 3 SMP Laboratorium Undiksha Singaraja terhadap penerapan metode pembelajaran IMPROVE mengalami peningkatan. Hal ini disebabkan karena di setiap kegiatan pembelajaran dengan metode pembelajaran IMPROVE mengajak siswa untuk fokus dan memusatkan perhatiannya dalam mengikuti proses pembelajaran sehingga terjadi interaksi antara guru dengan siswa. Selain itu, dengan penerapan metode pembelajaran ini siswa lebih antusias mengikuti pembelajaran. Ini terlihat dari rata-rata skor aktivitas belajar siswa mengalami peningkatan setiap siklusnya. Pada siklus I rata-rata skor aktivitas belajar siswa adalah 55,50 , kemudian pada siklus II adalah 58,36. Dari siklus I ke siklus II terjadi peningkatan sebesar 2,86, dari siklus II ke siklus III terjadi peningkatan sebesar 9,09, yaitu pada siklus III rata-rata aktivitas belajar adalah 67,45. Aktivitas belajar siswa meningkat dan berada pada kategori aktif.

Prestasi belajar matematika siswa Kelas VIII 3 SMP Laboratorium Undiksha Singaraja melalui penerapan metode pembelajaran IMPROVE mengalami peningkatan di setiap siklusnya. Peningkatan prestasi belajar matematika siswa disebabkan oleh langkahlangkah kegiatan pembelajaran yang terdiri dari : (a) menanamkan konsep kepada siswa di awal pembelajaran; (b) memberikanmetacognitive questioning yang terdapat pada LKS (c) mengorganisasikan siswa ke dalam kelompok-kelompok belajar; (d) mengulas kesulitankesulitan yang dialami oleh siswa (e) memberikan tes di akhir pembelajaran untuk mengetahui tingkat pengetahuan siswa (f) melakukan identifikasi terhadap hasil tes siswa $(\mathrm{g})$ memberikan verifikasi terhadap hasil tes yang diberikan siswa, apabila siswa mendapatkan skor dibawah KKM, diberikan remedial, apa bila tidak, maka akan diberikan pengayaan. 
Pembelajaran yang diterapkan membuat siswa memahami konsep dengan caranya sendiri melalui langkah-langkah dalam metode pembelajaranIMPROVE. Peningkatan prestasi belajar matematika siswa juga terjadi karena pertanyaan-pertanyaan yang bersifat menggali dan menuntun yang mengarahkan siswa untuk menemukan konsep yang sedang dipelajari. Peningkatan prestasi belajar dapat dilihat dari nilai rata-rata pemahaman konsep matematika siswa yaitu pada siklus I adalah 48,03 kemudian meningkat sebesar 18,64 pada siklus II menjadi 66,67, dan pada akhir siklus III rata-rata skor prestasi belajar matematika siswa adalah 75,76 meningkat sebesar 9,09 dari siklus II. Peningkatan optimal terjadi pada siklus III dan telah memenuhi indikator keberhasilan yang telah ditetapkan.

Rata-rata skor respon siswa kelas VIII 3 SMP Laboratorium Undiksha Singaraja terhadap metode pembelajaran IMPROVE adalah 69,03 dengan kategori positif. Pada saat pemberian angket oleh siswa 63,63\% ( 21 orang siswa) yang memberikan respon positif, dan $36,37 \%$ (12 orang siswa) memberikan respon cukup positif. Tercapainya indikator keberhasilan yang ingin dicapai peneliti yaitu respon siswa dikategori positif dikarenakan siswa mulai terbiasa dengan metode yang digunakan yang mana lebih menekankan siswa aktif bertanya, memberikan pendapat, menanggapi, memberikan gagasan sertamenemukan konsep melalui diskusi kelompok maupun sharing antar kelompok sehingga siswa dapat menambah pengetahuannya selain itu juga dapat membagi hal-hal yangmereka pahami dan ketahui tentang konsep kepada temannya.

Adapun saran dalam penelitian ini yaitu, Dalam rangka mengoptimalkan proses pembelajaran matematika, diharapkan kepada guru matematika Kelas VIII 3 SMP Laboratorium Undiksha Singaraja agar tetap menerapkan metode pembelajaran IMPOVE meskipun penelitian ini telah selsesai dilaksanakan. Metode pembelajaran IMPROVE dapat dijadikan alternatif untuk mengatasi rendahnya prestasi belajar dan aktivitas belajar matematika siswa.

Pembaca yang berminat untuk melaksanakan tindakan lebih lanjut mengenai penerapan metode pembelajaran IMPROVE diharapkan agar memperhatikan kendalakendala yang dialami selama pelaksanaan penelitian sebagai bahan pertimbangan untuk perbaikan dan penyempurnaan pelaksanaan penelitian.

\section{Daftar Pustaka}

Alci. 2015. Implementasi Strategi Pembelajaran Active Knowledge Sharing untuk Meningkatkan Aktivitas dan Prestasi Belajar Matematika Siswa Kelas VIII C SMP Negeri 3 Singaraja. Skripsi. Tidak Diterbitkan. Universitas Pendidikan Ganesha.

Aritami. 2012. Pengembangan Pembelajaran Aktif dengan ITC. Jakarta: Sripta Media Creatif. Arikunto, S. 2002. Dasar - Dasar Evaluasi Pendidikan. Jakarta: Bumi Aksara.

Arikunto, S dkk. 2012. Penelitian Tindakan Kelas. Jakarta: Bumi Aksara.

Candiasa, M. 2010. Statistik Univarian dan Bivarian disertai Aplikasi SPSS. Singaraja. Unit Penerbitan Universitas Pendidikan Ganesha.

Depdiknas. 2003. PERMEN 22 Th. 2003-Sistem Pendidikan Nasional. Jakarta: Dirjen Manajemen Pendidikan Dasar dan Menengah, Diknas.

Hamalik, O. 2006. Proses Belajar Mengajar, Jakarta: Bumi Aksara

Martinis, Yamin. 2007. Pembelajaran Aktif. Bandung: PT Remaja Rosdakarya.

Mutaharoh, 2011. Pengaruh Metode Konvensional di Kelas terhadap Siswa . Bogor: Jaya Abadi.

Mulyasa, E. 2006. Kurikulum Tingkat Satuan Pendidikan. Bandung: Remaja Rosdakarya.

Nurhayati, D. 2014. Psikologi Belajar Mengajar. Bandung: Sinar Baru Algesindo.

Nurkancana, W. dan Sunarta. 1992. Evaluasi Hasil Belajar. Surabaya: Usaha Nasional.

Suherman, E. 2008. Model Belajar dan Pembelajaran Berorientasi Kompetensi Siswa. Jurnal Pendidikan dan Budaya. 5(2). 1-30. Tersedia pada http://educare.e-fkipunla.net. Diakses pada 11 Januari 2017. 
Jurnal Pendidikan dan Pembelajaran Matematika Indonesia

Vol. 7 No. 1, Tahun 2018

e-ISSN : 2615-7454

Susilo. 2012. "Pandangan Konstruktivisme Mengenai Proses Belajar". Tersedia pada http://www.eurekapendidikan.com/2014/10/pendangan-konstruktivismemengenai.html\#more (diakses tanggal 13 Januari 2017).

Oktarini (2015). Peningkatan Literasi Matematis Siswa Melalui Pendekatan Metacognitive Guidance. Tesis SPS UPI

Bandung: Tidak Diterbitkan

Yuningsih, D. 2013. Penerapan Metode Pembelajaran IMPROVE untuk Meningkatkan Hasil Belajar Siswa dalam Pembelajaran TIK. Skripsi. Tidak diterbitkan. Universitas Pendidikan Indonesia.

Jurnal Pendidikan dan Pembelajaran Matematika Indonesia 78 